\title{
PRAGMATIC ANALYSIS OF MODIFIED MACHIYA INHABITATION
}

Culturally friendly design method based on Machiya system of Kyoto (Part 2)

\author{
改変された町家における居住に関する実用論的分析 \\ 京都の町家システムに基づく文化親和型の設計方法（その 2 )
}

\author{
Fabian JANDER* and Teruyuki MONNAI** \\ ファビアン ジャンダ, 門 内 輝 行
}

\begin{abstract}
In this paper different cases of Machiya and modified Machiya are being analyzed. In the previous part a survey of semantic parameters is used in order to understand Machiya dwelling typology; now individual cases are analyzed with the same method, compared with the Machiya typology and complemented with syntactic analysis to see how they are related to Machiya.

We found that we can distinguish different ways of conserving correlation with Machiya: some cases conserving more semantic qualities and others conserving more syntactic qualities; the semantic qualities define the identity and context, while the syntactic qualities define particularities. We could differentiate the impact of physical modifications and the impact of the interpretation of the inhabitant, showing both to be relevant in defining a building.
\end{abstract}

Keywords: Machiya, Inhabitation, Syntactic analysis, Semantic analysis, Pragmatic Analysis 町家，居住，構文論的分析，意味論的分析，実用論的分析

\section{Introduction}

In actual context of various vernacular building typologies around the world, including Machiya, we are concerned about the fact that the museumization ${ }^{* 1}$, 1), 2) of hyposignificant ${ }^{* 2), 3)}$ public space might extend to the vernacular dwelling typologies. It is to say, that existing vernacular typologies might become seen by the inhabitants of the cities as museum pieces; just something to look at.

In part $1^{4)}$ we made a semantic analysis differentiating Machiya from other dwelling types ${ }^{*}$ ). But as well we found a discrepancy between the semantic space of existing Machiya and the type of dwelling preferred by those who say that they would like to live in Machiya, showing that even if inhabitants can recognize semantic space of Machiya they might not necessarily be aware of the implications of it. Therefore, in this paper we will use the semantic analysis from part 1 and compare it with specific cases and complement it with syntactical analysis. This way we should be able understand each case within its semantic context and see how such case is related to Machiya regarding its inhabitation and not only formal aspects.
Such method is not based on interpretation or analysis of form only, since even the most perfect "replica" will be subject to museumization; therefore, we use the semantic and syntactic analyses of the inhabitation of vernacular dwellings (in this case Machiya), rather than the form of Machiya*4),5). Moreover, we should be able to find Machiya with new forms.

\section{Concept of Machiya}

We can find many different approaches to Machiya, but only a small fraction focusing on inhabitation or inhabitants interpretation. Examples of other approaches might include structural approaches ${ }^{6}$, 7 ), or approaches regarding thermal performance comparing to modern context $^{8}$, about the historical streetscapes9),10) and historical urban context11), 12). Additionally we can find researches on the development of Machiya as vernacular architecture ${ }^{13), 14), 15)}$, some focusing on the importance of the meaning of Machiya in actual context ${ }^{16)}$, 17), new possibilities for Machiya ${ }^{18}$, the role of the community ${ }^{19)}$, and as well as guidelines for cases of Machiya modifications ${ }^{20}$. As well we can find syntactic analysis such as space $\operatorname{syntax}^{21)}$ and

* Architect, Dr. Eng.

建築家 博士(工学)

* Prof., Department of Architecture and Architectural Engineering, Graduate School of 京都大学大学院工学部研究科建築学専攻 教授·工博 
schema grammar ${ }^{22}$, but even in such cases focusing more on the physical space than the inhabitants' interpretation.

For this research, we will use our previously made semantic definition as a complementary definition of Machiya based on the interpretation of the inhabitants (semantics), and compare it with existing research.

\section{Semantic analysis}

\subsection{Preliminary semantic analysis}

This section is a summary of part 1 and will be used as semantic reference of Machiya in actual context ${ }^{* 5}$, 4).

The hypothesis of this preliminary analysis is that the inhabitants can still recognize certain pattern of semantic characteristics regarding inhabitation corresponding to Machiya; such pattern would be different from other building typologies.

In part 1 we could asses such pattern with an semantic analysis where 215 people participated answering a questionnaire and rating four "semantic dimensions" (explained in next paragraph) for each activity of a list of 13 activities $\left.\left.{ }^{*}{ }^{6}\right), 23\right)$ (1-entering, 2-breakfast, 3-lunch, 4-dinner, 5-cooking, 6-sleeping, 7-washing (shower), 8-bathing, 9-clothes washing, 10-clothes drying, 11-leisure, 12-study/reading and 13-work). The data was classified according to dwelling type, then calculated the average for each activity and plotted in a four dimensional graph for each dwelling type (graphs as described next and in part $1^{4)}$ ).

The four semantic dimensions used in part 1 are:

Formality is an adaption to the concepts used in the traditional space of Machiya to distinguish ordinary activities represented in space mainly by the doma, and extraordinary activities, represented mainly by tatami rooms. Elements such as doma or tatami have a meaning according to how formal the activity realized in such space might be, and will be disposed in a formal order in Machiya.

Privacy is an adaptation of the traditional meanings of uchi and soto, which in the case of Machiya as well had an special spatial hierarchy, where we can distinguish different degrees from the street towards the back of the Machiya, having a spatial meaning for the activities realized in the front or the back of the house.

Brightness is related to the internal order of bright and dark inside of Machiya, and has also an important meaning for orientation, as for example in dark spaces from which inhabitants can appreciate the light received by the garden. Also it is an important topic in Japanese esthetics ${ }^{24)}$.

Naturalness is related to the characteristic sense of nature present in Machiya ${ }^{* 7), 25)}$ represented mainly by gardens, which as well have an important meaning for the activities realized in the spaces connected to the gardens, such as the zashiki.

As result we can have a pattern of 13 four dimensional points (4 semantic dimension for 13 activities). For each dwelling type such pattern is different. And the pattern generated by Machiya inhabitants will correspond to Machiya layout (also as in part 1):

In part 1, in order to check if the resulting pattern corresponds to Machiya, we used the particularity of Machiya layout to reflect its main semantic order (formality and privacy) in an orthogonal way as in Fig. 1. So we can estimate if the activities from the list should be formal, informal, private or public according to such layout (Fig. 1). Then we compare Fig. 1 with the four dimensional graph made with our data (Fig. 2)*8).

The figures in this paper correspond to an updated version of part 1 including the case studies totaling 223 people ${ }^{* 9}$ ).

To elaborate Fig. 2 we used the average values of each semantic dimension for each activity corresponding to Machiya (as previously mentioned) in a four dimensional graph as follows: Axis X (horizontal) indicates average formality, axis Y (vertical) average privacy, the shade of the bubbles indicates average brightness $($ dark $=$ dark, light $=$ bright $)$ and the size of the bubbles indicates average naturalness $($ bigger $=$ more naturalness $)$.

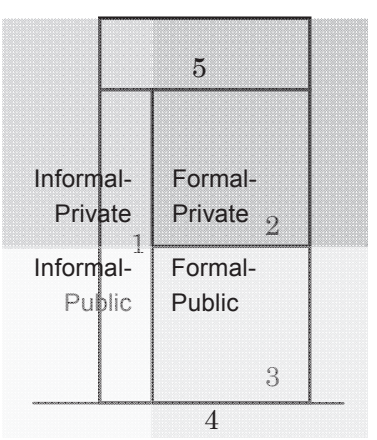

1: Tooriniwa, space with earthen floor for informal activities such as cooking and washing.

2: formal living space, usually tatami rooms used for living space and eating.

3: Mise, working space used as shop, open to public.

4: Street

5: Garden on the back side of the House

Fig. 1 Scheme of semantic division of Machiya layout, directions are symbolic and do not always fit equally in all Machiya.

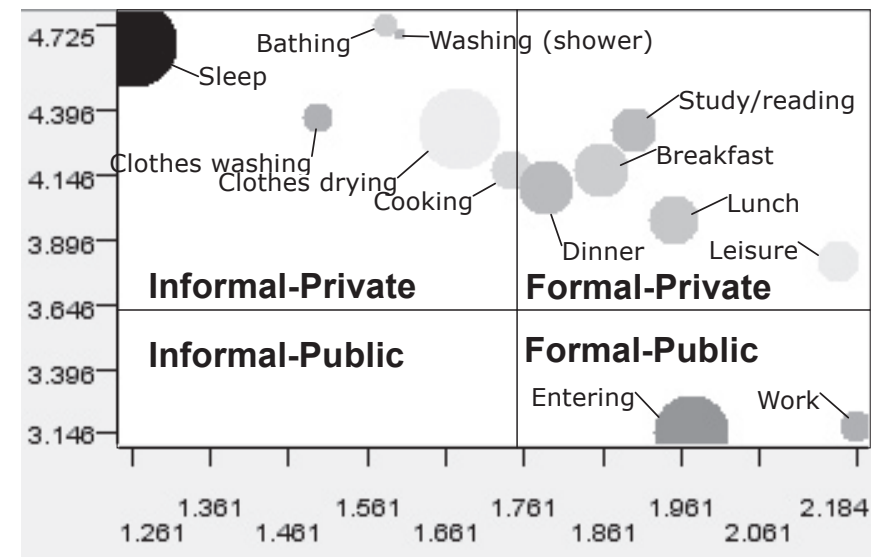

Fig. 2 Graph corresponding to semantic pattern based on Machiya inhabitants data divided into semantic quarters as the Machiya layout in Fig. 1. Axis X (horizontal) indicates average formality, axis $\mathrm{Y}$ (vertical) average privacy, the shade of the bubbles indicates average brightness $($ dark $=$ dark, light $=$ bright $)$ and the size of the bubbles indicates average naturalness $($ bigger $=$ more naturalnesS $)$.

Still we can find some exceptional points (also mentioned in part 14)): sleeping, which in fact would be located in the second floor of Machiya and resulted as the most informal and private 
activity in Fig. 2. Also entering appeared as a formal activity on Fig. 2, but we can notice that entering is the most informal of the public activities (on the left of work).

We should also notice that the living space corresponding to eating (ダイドコ) is identified in “京町家塾 町家って何?”15) as corresponding to the DK in modern dwellings. But we have to notice, that the dinning kitchen system joined the kitchen and dining functions, and also tend to replace the formal reception function of the zashiki aiming towards a "family centered home" ${ }^{26)}$. But as we might noticed in part 1, in our data corresponding to "Houses", eating activities in average have almost the same formality as cooking, and in "Other buildings" eating activities are considered in average less formal than cooking by the inhabitants*10).

\subsection{Specific semantic analysis of cases}

This analysis will be the same as the previously mentioned in section 3.1 and explained more in detail in part 1, but now done with the data of the selected cases. Additionally we use cluster analysis in $\mathrm{KNIME}^{* 11}$ on the semantic data of each case. The aim of the cluster analysis is to find clusters of activities closer related to each other according to their semantic dimensions.

The cases and the results of this analysis will be explained in section 6. And as reference of Machiya we use the result of section 3 (Fig 2).

\section{Syntactic analysis}

This analysis is applied to each case together with the semantic analysis previously explained.

The data collection for the syntactic analysis consists in visiting the house of one subject as case study. The cases are selected in order to understand how modified Machiya can remain being Machiya or not, including atypical Machiya from the questionnaire data base and new cases of our concern (in this paper only a selection of case studies is presented). Each of the subjects of the case study is requested to fill out the previously described questionnaire and to explain in which space of her/his house she/he does each of the activities listed in the questionnaire (see section 3 and/or part 14)).

For the syntactic analysis graph theory is used. In some occasions in architectural analysis using graph theory nodes may correspond to spatial units ${ }^{21}$, but in this case as some spaces are used for different activities depending on the inhabitant, we use the same 13 activities as in the questionnaire as nodes. The edges will be labeled edges, and the label will correspond to elements we can find between the activities defined as follows:

a) Same: corresponds to activities done in the same space.

b) Void: corresponds to void spans between activities, with no panel or glass as separation.

c) Sliding: corresponds to sliding panels such as fusuma and shoji.

d) Doors: corresponds to conventional non-transparent swinging doors.

e) Window-doors: corresponds to glass doors or windows that can be opened in a way that it is possible to walk through.

f) Window: corresponds to windows that only allow to see through, but not to walk through.

g) Verandah: corresponds to an Engawa or similar verandah.

As activities may occur in various spaces simultaneously activities can be connected to themselves or have multiple connectors ${ }^{*} 12$ ). The results of theses analyses are in section 6 .

\section{Pragmatic Analysis: Relation of semantic and syntactic analysis}

It is important to notice that the data from each case study is linked to its semantic context through the semantic dimensions; as for example, if a subject answers that she/he lives in a Machiya, all the semantic information about the activities she/he answers can be compared to all the other data corresponding to Machiya (see section 3 or part 14)). Therefore the case selection is aimed to understand even single cases of our interest.

With the semantic data it is already possible to find out what activities are semantically related or not. With the syntactic analysis we can see if activities semantically related are spatially linked or correspond to spatial structures of the house. The relation of inhabitant's interpretation and context corresponds to pragmatic dimension.

\section{Analysis applied on modified Machiya}

Once the context of the research has been explained in the previous sections; in this section, within the previously explained data, Machiya and modified cases of Machiya will be analyzed.

\subsection{Case 1}

This case (left on Fig. 3) is chosen as representing well conserved Machiya, and figured as the best evaluated case in a previous research ${ }^{5}$. As can be seen in Fig. 4, in this case we will analyze the inhabitation of a large Machiya. Also the inhabitant of this house considers her lifestyle as Machiya lifestyle.

If we consider the semantic analysis of activities, Fig. 5 represents the semantic data as parallel coordinates corresponding to case 1 , with the respective dendrogram), we can recognize that we will have mainly two clusters: Cluster A corresponding to informal-private activities, which are as well brighter than the activities in Cluster B, corresponding to formal-public activities. Such division of space can be easily associated not only with formality and privacy, but with the Japanese idea of Omote-Ura (see predominant semantic aspect as arrows in Fig. 5) or in combination with Kami-Shimo as in reference 22). As explained by the owner of the house, many activities are in fact different for guests (more public) and the 
family (more private); as can be seen in Fig. 4 activities in several cases have different location for guests, or for family use.

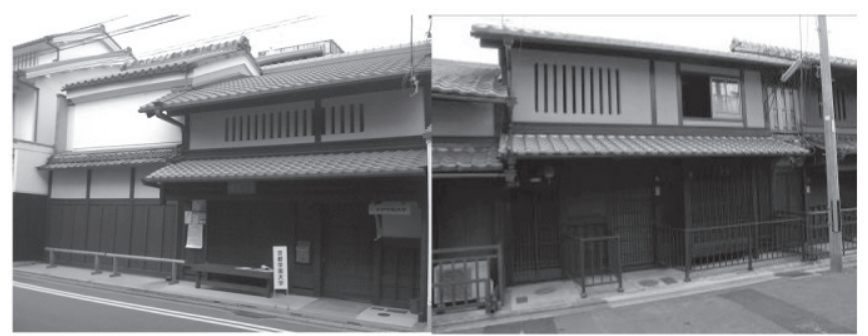

Fig. 3 House corresponding to case 1 (left) and case 2 (right).

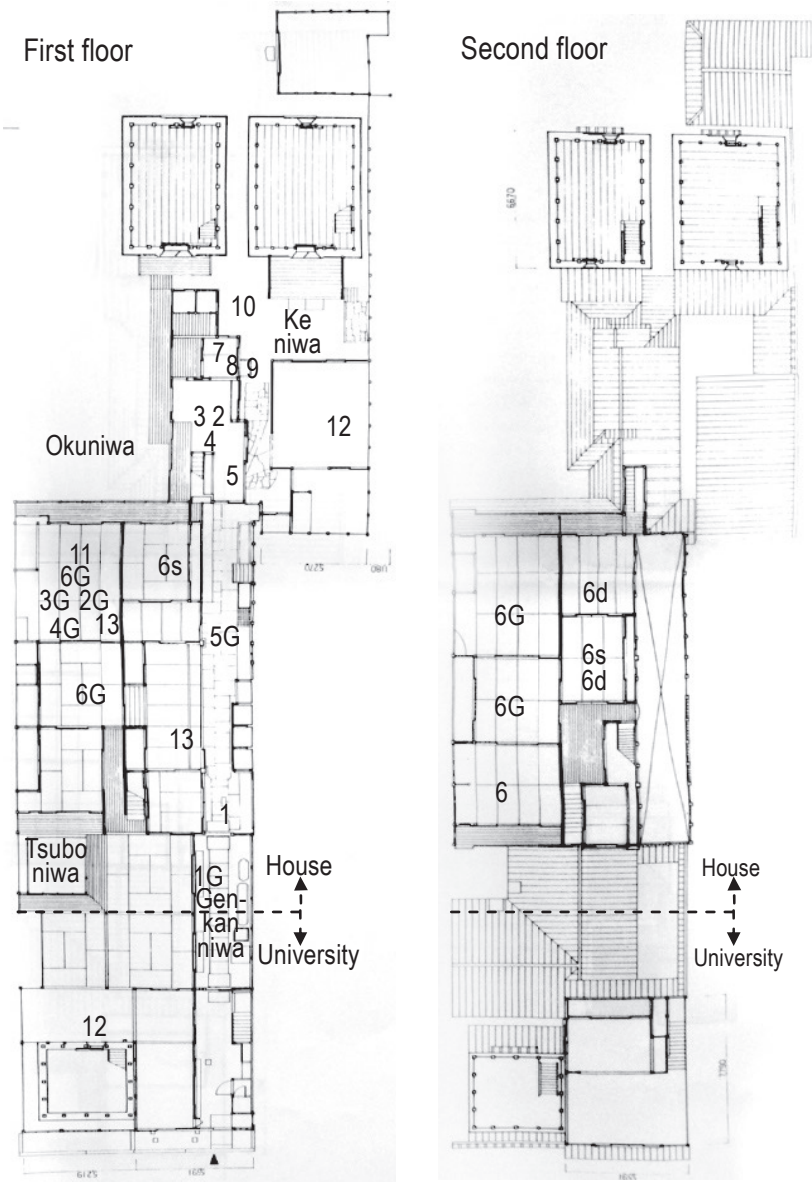

Fig. 4 Case 1 floor plans: 1 Entering; $1 \mathrm{G}$ Guests' entering; 2 Breakfast; 2G Guests' breakfast; 3 Lunch; 3G Guests' Lunch; 4G

Guests' Dinner; 4 Dinner; 5 Cooking; 5G Cooking for guests; 6

Sleeping; 6G Guests' Sleeping; 6s Sleeping in summer; 6d

daughters' Sleeping; 7 washing (shower); 8 bathing; 9 clothes washing; 10 clothes drying; 11 Leisure; 12 Study/reading; 13 Work.
In this case where it was considered by the inhabitant to mention a special value for guests and her own, both values were written in the data set and for Fig. 5 an average value is used.

The tooriniwa played a leading role in the semantic description of the case. Even if in a general tendency family activities were considered as informal (formality 1), and activities done by guests as formal (formality 5), activities such as bathing and washing done in common space for family and guests at the back of the tooriniwa (Fig. 4) remained as considered informal for both, family and guests. In the case of cooking it is also considered a different space for cooking for family and for cooking for guests, but both located in the tooriniwa and should not be accessed by guests, therefore in average both remained less formal than other activities considered as formal for guests.

The place where the family do breakfast, lunch and dinner is in this case informal, and is as well located at the back of the tooriniwa next to the family's cooking space (Fig. 4). This situation would be seen as a semantic shift towards a joint eating and cooking space for the family as an informal space (see for comparison Fig. 2 for details of semantic description of eating activities and cooking based on average data of Machiya). In this case, including the guests, we could say that the traditional semantic order of Machiya appears matching its syntactic order.

As for activities not been done in the tooriniwa such as leisure and sleeping: we can notice more flexibility for sleeping shown in different places in Fig. 4, remaining formal for guests and informal for the family, while leisure even in the case of family is considered only slightly informal, resulting in the highest formality in average (Fig. 5).

In the syntactic analysis (Fig. 6), we considered the panels of wood with glass separating the tooriniwa and the formal space as different than the light partitions used in the formal space, so we can easily distinguish the informal side on the left of Fig. 6 defined by doors and voids and the formal side on the right of the graph defined by sliding panels. So we can say that the connectors in Fig. 6 have semantic meaning in this case.

The only exception within the tooriniwa would be the entering space in the genkan niwa (on the right in first floor plan Fig. 4), which would be the only less informal activity completely located

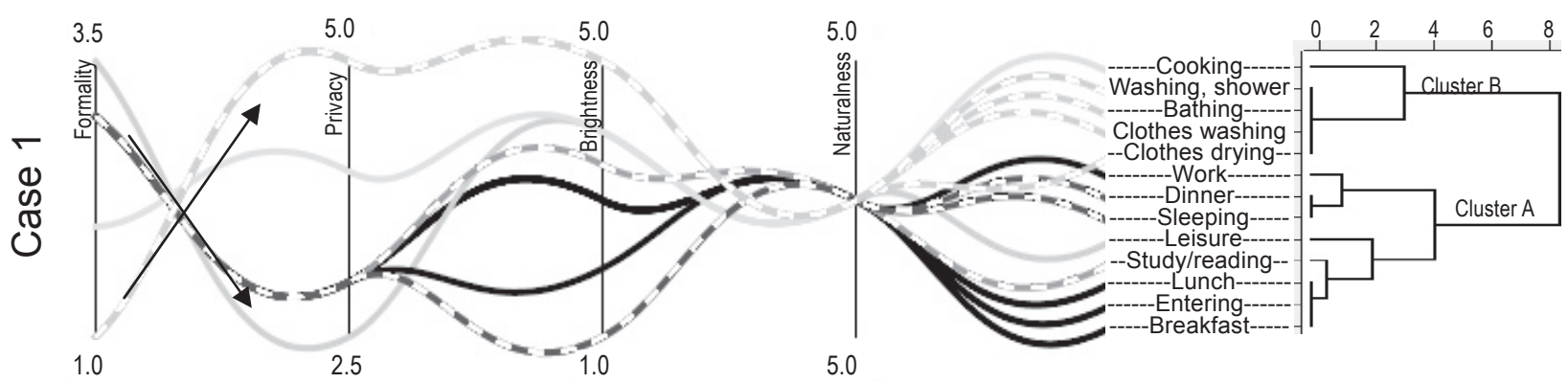

Fig. 5 Parallel coordinates representing the semantic data provided by inhabitant of case 1and Dendrogram of cluster analysis of such data. 
in the tooriniwa for guests and family (Fig. 4). But such exception if in fact coherent with the fact that in Fig. 2 there is no public-informal activity, and entering is in average of Machiya considered as a more formal activity than other activities located in the tooriniwa.

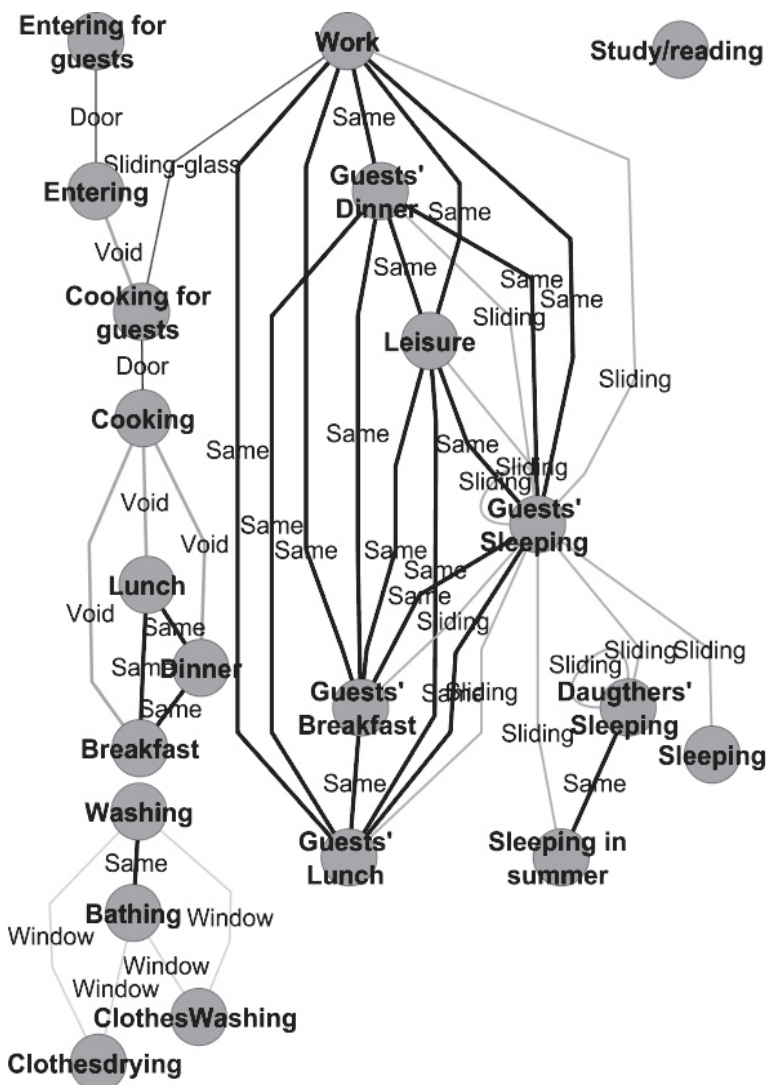

Fig. 6 Syntactic activity graph corresponding to Case 1. We can distinguish the tooriniwa on the left and tatami rooms on the right. Graph elaboration is explained in section 4.

\subsection{Case 2}

The second case (Fig. 3, right and Fig. 7) corresponds to a two story Machiya in Nishijin district with long tradition ${ }^{27)}$. The house remained almost unchanged for a long period, but after remaining unoccupied for a time, it became damaged. After major repairs of the roof a foreign architect started to live in the house and continues repairing it in a traditional way. At the moment this paper is written, only the first floor was inhabited. We selected this case in order to analyze Machiya in reparation.

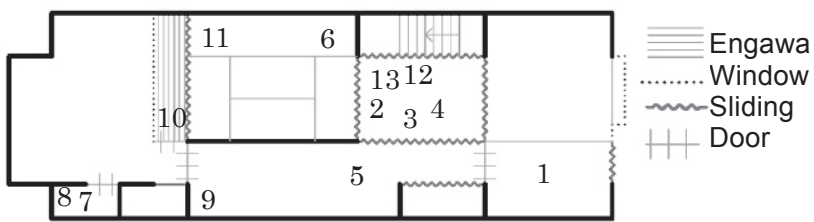

Fig. 7 Case 2: 1 Entering; 2 Breakfast; 3 Lunch; 4 Dinner; 5 Cooking; 6 Sleeping; 7 washing (shower); 8 bathing; 9 clothes washing; 10 clothes drying; 11 Leisure; 12 Study/reading; 13 Work (the second floor is not yet being used)
We can recognize that there is a living core composed of the activities breakfast, lunch and dinner (Cluster A in Fig. 8 and 9); grouped with work, leisure and study in cluster B. In this case the core is defined by activities in the same space (except Leisure), and related to the rest by sliding panels (Fig. 8). As well cooking, even if well connected to such core is in cluster together with clothes drying and clothes washing (Fig. 9) (in Machiya these activities would correspond to less formal than activities such as breakfast, lunch, dinner, leisure, study or work).

In this case, despite that the repairs are not finished, as for the syntactical order (Fig. 8), it keeps resemblance to Machiya as we can recognize for example the tooriniwa with the entrance connected to cooking space and the latter to connected with a void to clothes washing and with sliding panels to the living core (still we can see that there is a great number of activities in the same space as not many rooms are able to be used yet). If in the dendrogram (Fig. 9) we look at higher hierarchy, we can see that Cluster B corresponds to tatami rooms, Cluster C to tooriniwa and Cluster D to temporary or unfinished spaces; there is a strong correlation of physical space and semantic data clustering. But we have to consider that formality is not perceived as in traditional Machiya in this case, as almost all activities are considered as informal (Fig. 9), therefore, this case resembles Machiya syntactically more than semantically, which means that this Machiya is being inhabited in a new nontraditional way but keeps physical order of Machiya, despite the repairing.

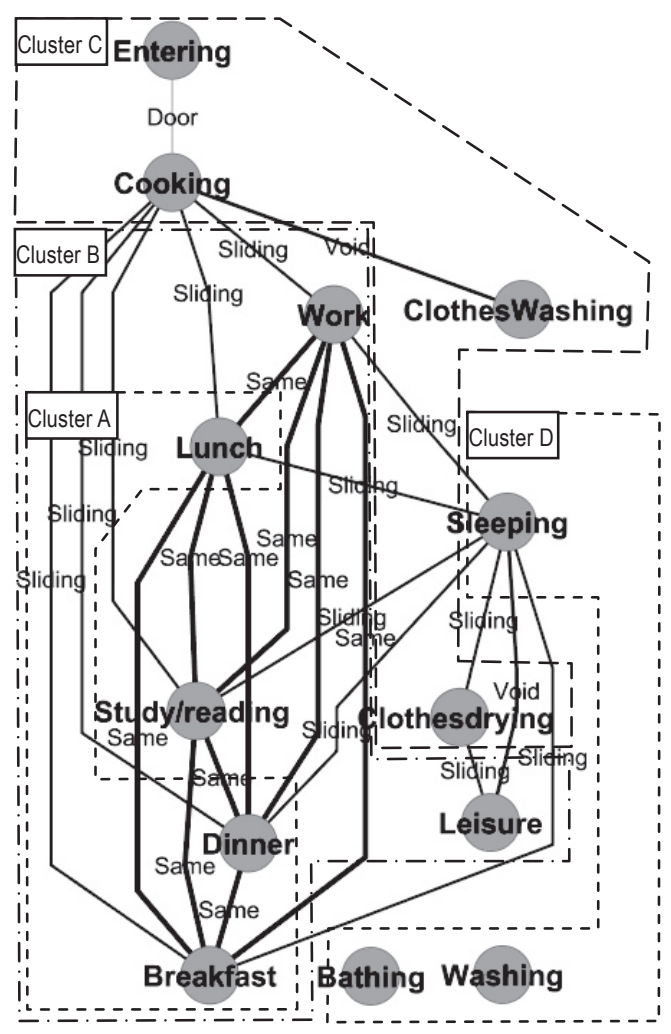

Fig. 8 Syntactic activity graph corresponding to Case 2. Dotted lines indicate clusters as in Fig. 9. 


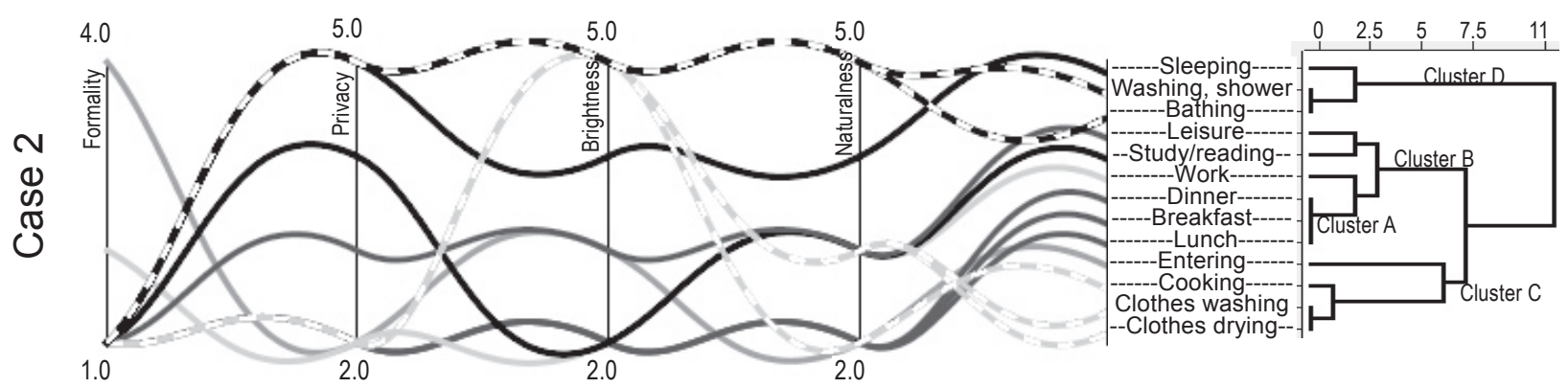

Fig. 9 Parallel coordinates representing the semantic data provided by inhabitant of case 2 and Dendrogram of cluster analysis of such data.

\subsection{Case 3}

Case 3 (Fig. 10): the third case corresponds to a three story Machiya that has suffered major modifications; its first floor is used for parking, second and third floors are divided in rental dwellings while the owners live in a new built house in the back of the former Machiya, moreover the entrance is on the back side (Fig. 11). To analyze a much modified case we selected this case.

For the analysis of this case, the average of semantic data from two different inhabitants of the same house is used. Those data are recollected with inhabitation questionnaire (one person answered that this house is Machiya, while the other answered that it is a House different from Machiya). As for syntactic analysis (Fig. 12) two nodes are used for sleeping and study/reading corresponding to the two inhabitants.

At a first glance case 3 might not fit into any category, as it is a hybrid between Machiya and other type of house. For example, considering the formality (Fig. 13) we can see that the pattern of case 3 is more likely not Machiya as most activities are considered as informal so we cannot associate the sliding panels to formal tatami rooms anymore (as in case 1). While the privacy of the case study seems atypical, because of Cluster A (Fig. 12); the activities, breakfast, lunch, dinner, cooking and leisure are in this cluster with relatively low privacy (Fig. 13), suggesting that in the case, such activities are done in shared rooms, different from the average values of other typologies. This particularity reflects the change of use of the building; a rental dwelling shared by inhabitants who are not family, whereas the low formality is reflecting the internal renovation made in style of non Machiya houses.

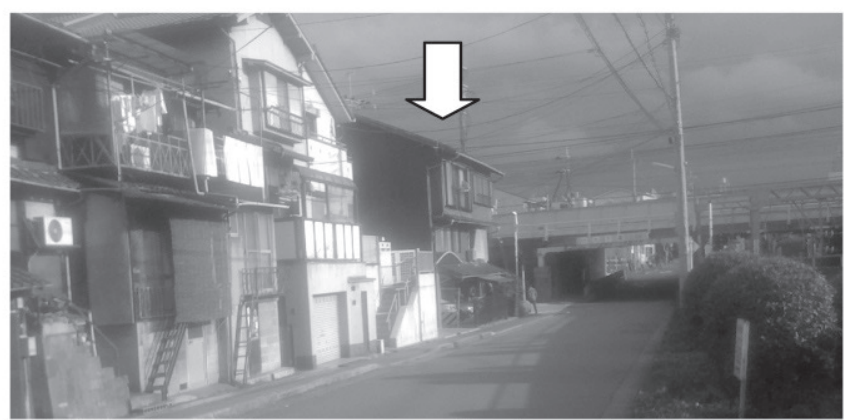

Fig. 10 Façade of house corresponding to case 3 and neighbors.
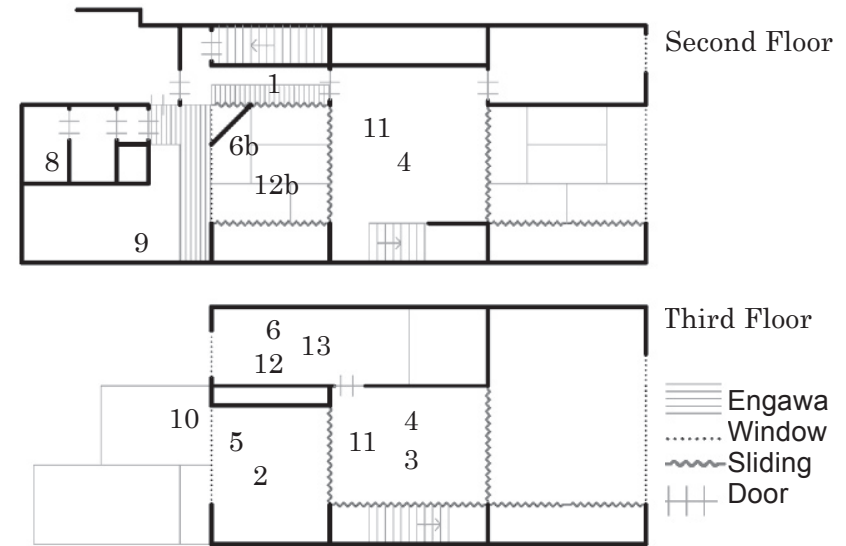

Third Floor

Fig. 11 Case 3: 1 Entering; 2 Breakfast; 3 Lunch; 4 Dinner; 5 Cooking; 6 Sleeping; 6b Sleeping 2 Sleeping; 7 washing (shower); 8 bathing; 9 clothes washing; 10 clothes drying; 11 Leisure; 12 Study/reading; $12 \mathrm{~b}$ Study/reading 2; 13 Work (the first floor is parking space)

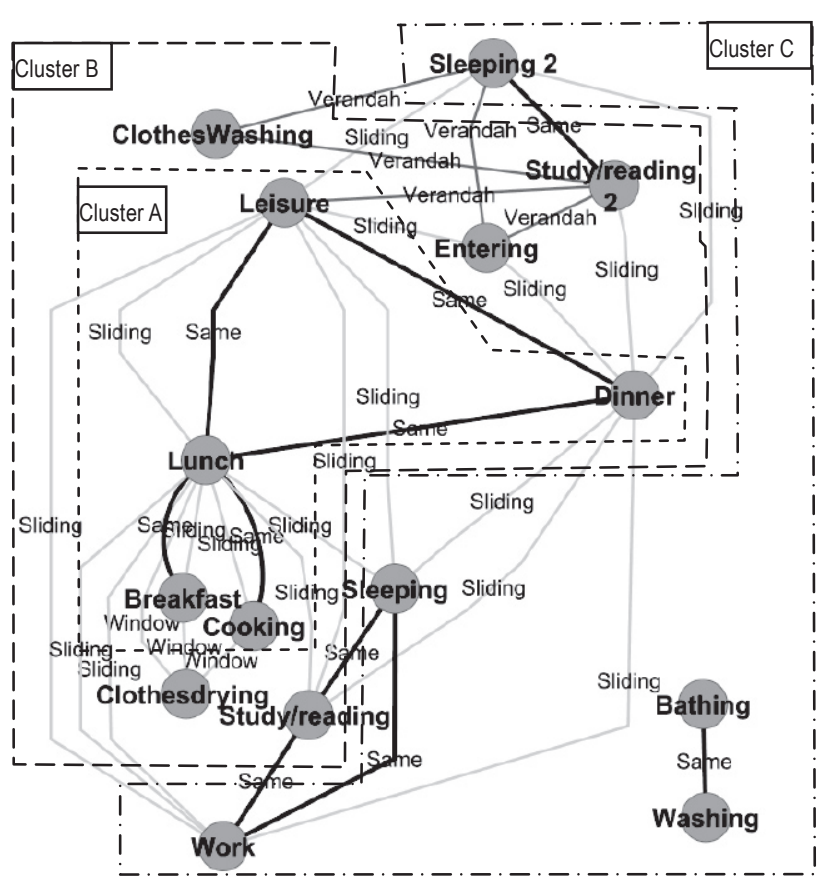

Fig. 12 Syntactic activity graph corresponding to Case 4. Dotted lines indicate clusters as in Fig. 13.

Looking at Fig. 12 we can notice several particularities:

-The 2 different sleeping activities, corresponding to each inhabitant are connected in a very different way (Fig. 12). One inhabitant sleeps in a space used as well for study and work, in a way as personal room connected to an eating/leisure space, while 


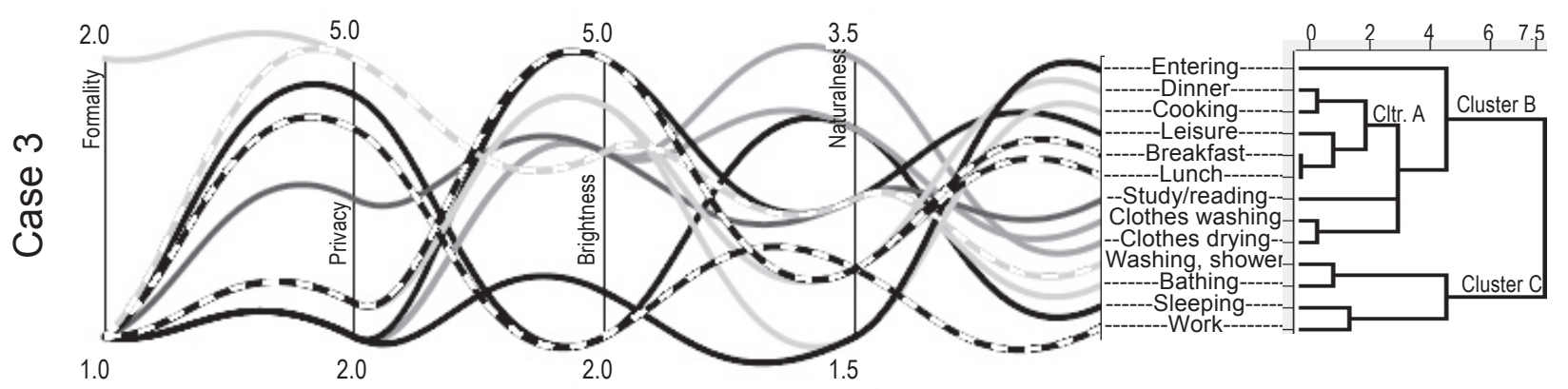

Fig. 13 Parallel coordinates representing the semantic data provided by inhabitant of case 3and Dendrogram of cluster analysis of such data.

the other inhabitant also has a room for sleeping and study, but connected to the entrance, clothes and a space for shared use for leisure and dinner, but not other meals.

-Among the eating activities, cooking and leisure we can see ambiguous or double connections, indicating that more than one space is used for the same activities, while the sleeping spaces are well defined as individual rooms. This inhabitation pattern reflects the common areas and personal rooms of a shared house.

-There is not a clear order where we could recognize a formal or an informal part, as the ambiguous use of common space connects almost everything with sliding panels, and only a verandah system might be associated with another group of activities connecting Entering, Bathing and washing, with the second study/reading and sleeping. But these connections cannot be clearly associated with Machiya inhabitation systems.

Considering Fig. 13, in a higher hierarchy, we can see clusters B and C. Cluster B will correspond to the shared activities and C to the private activities. This would be a brief outline of the perceived inhabitation of this shared house. We can notice strong influence in the privacy levels difference of the shared activities in contraposition of well defined personal space.

As result of the modifications and given use we cannot recognize the Machiya systems such as tooriniwa, formal living rooms, or shop (mise). Neither the semantic data reflects much of Machiya identity; therefore we could say that this is not a real Machiya anymore, but indeed a share house.

\subsection{Case 4}

Case 4 corresponds to a renovated Machiya, but intentionally designed in order to be a modern Machiya (Fig. 14, left). The house is a narrow Machiya 5 meters wide and 25 meters long, originally composed of one row of five sections, with a garden
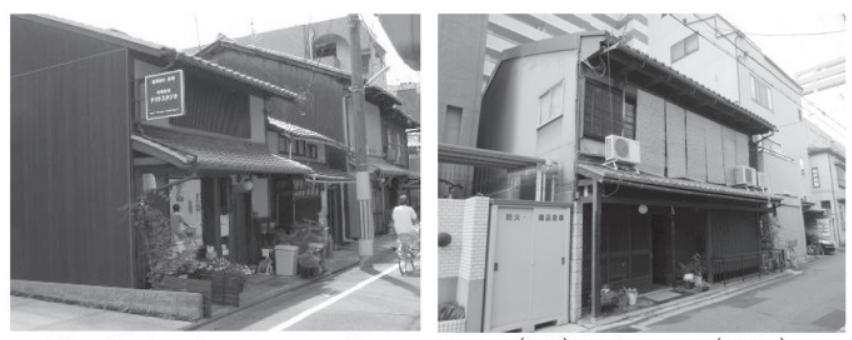

Fig. 14 Façade corresponding to case 4 (left) and case 5 (right). between the third and fourth section (counting from the street to the back). This house before being renovated had already a kitchen with raised floor, but not fully converted into DK or LDK system, as the kitchen was not yet joined together with a dining room (Fig. 15). This case is selected to show new Machiya types.

After the renovation the house was transformed into residence and office. Contrary to traditional Machiya in this case the office space uses the full area of the first floor (In Fig. 16 we can see the connected activities Entering, Lunch, work and Study/reading (Lunch is in this case in the office space (Fig. 15))), while the second floor remains as residence. Another particularity is the use of system kitchen in a space joined with dining room, making it somewhat similar to the DK system.

Fig. 17 we can realize that in this case the main semantic
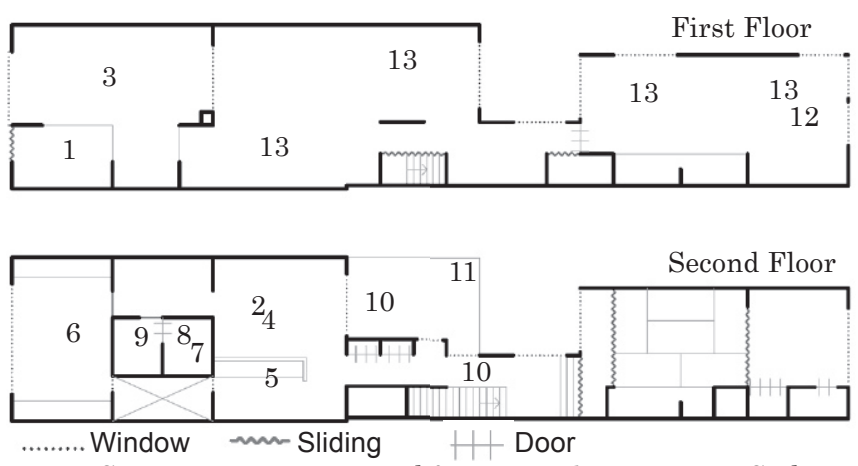

Fig. 15 Case 5: 1 Entering; 2 Breakfast; 3 Lunch; 4 Dinner; 5 Cooking; 6 Sleeping; Sleeping; 7 washing (shower); 8 bathing; 9 clothes washing; 10 clothes drying; 11 Leisure; 12 Study/reading; 13 Work

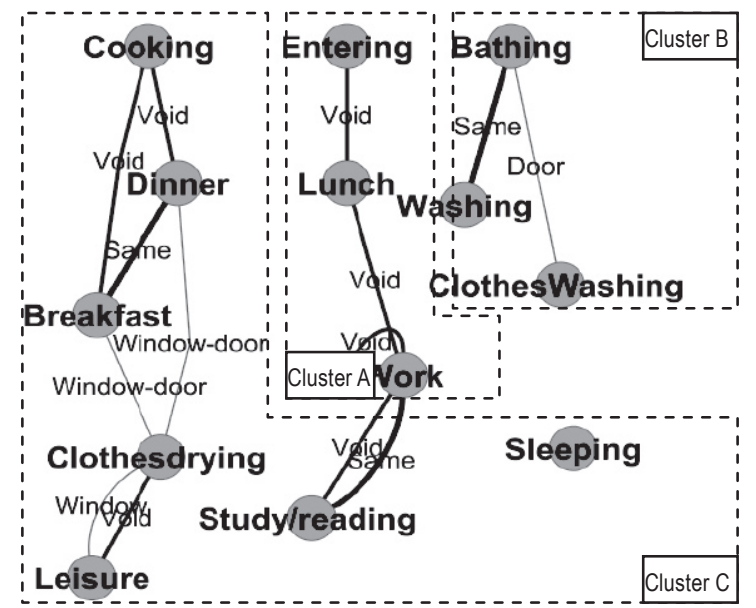

Fig. 16 Syntactic activity graph corresponding to Case 4. Dotted lines indicate clusters as in Fig. 16. 


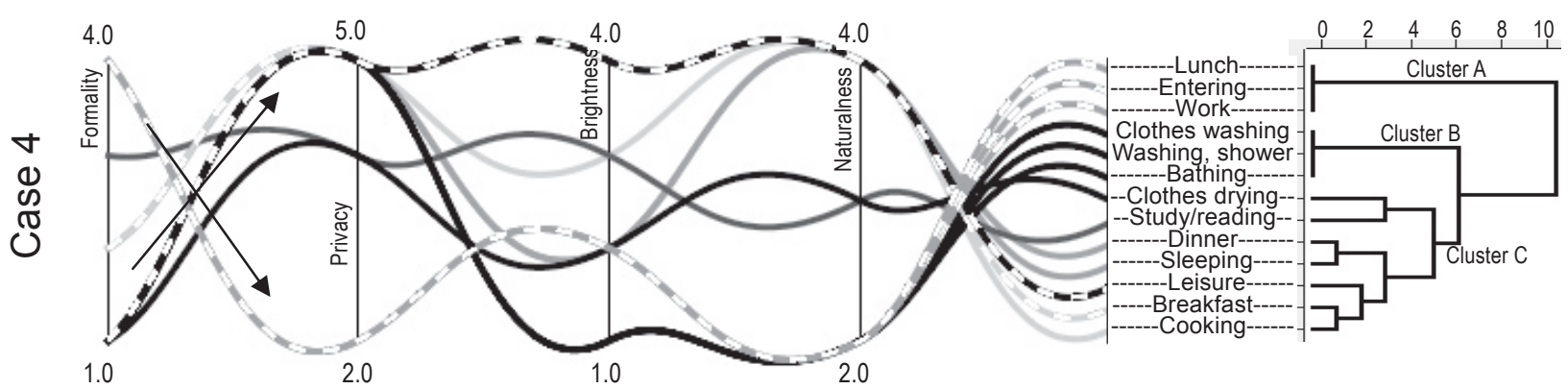

Fig. 17 Parallel coordinates representing the semantic data provided by inhabitant of case 4 and Dendrogram of cluster analysis of such data.

dimensions (formality and privacy) still have certain correlation with the Machiya definition in Fig. 2; entering and work remain formal-public; Cooking, Sleeping, Washing, Bathing, Clothes washing and Clothes drying remain informal-private; while Study/reading remains formal-private. We can realize that in this case lunch, entering and work appear in one cluster (Cluster A in Fig. 16 and Fig. 17) with high formality. These three activities all occur in the first floor; in the office space. If we look at Fig. 16 we can see that only study/reading appear connected to these activities, but it is located only in part of the working space keeping more privacy (Fig. 17). We can therefore recognize that the first floor would, in this case, correspond to the formal-public side; while the informal-private living space is divided mainly by naturalness into Cluster B and Cluster C (Fig. 17). Still we can recognize in Fig. 17 the predominant separation of public-formal and private-informal (as shown by the arrows in a similar way as in case 1 (Fig. 5)), with the exception of study/reading, which is private-formal but located in the first floor.

In this case we can find an overall semantic similarity with Machiya (9 out of 13 activities remain correlated with Fig. 2 as explained in the previous paragraph); therefore we can say it is a kind of Machiya. Only 4 activities have different main semantic dimensions than in Machiya (Lunch is public, Dinner, Breakfast and Leisure are informal (Fig. 17)), resulting in a particular semantic clustering, which tend to match the syntactic order of the building (except for study/reading). But as the syntactic systems in Fig. 17 are different from Machiya, this will be considered as a new or different kind of Machiya.

\subsection{Case 5}

This case is a well maintained 100 year old two story Machiya in Shimogyo-Ku, Kyoto. This house would be considered as a typical Machiya (Fig. 14, right and Fig. 18): it has a wooden façade with lattice windows in the first floor and windows with sudare in the second floor and so on. The most significant modifications include a new dining kitchen connected to the entrance in the first floor (cluster A in Fig. 19) and a new office style working room in the second floor over the kitchen.

This case is selected to show the impact of common internal modifications, such as dining kitchens.

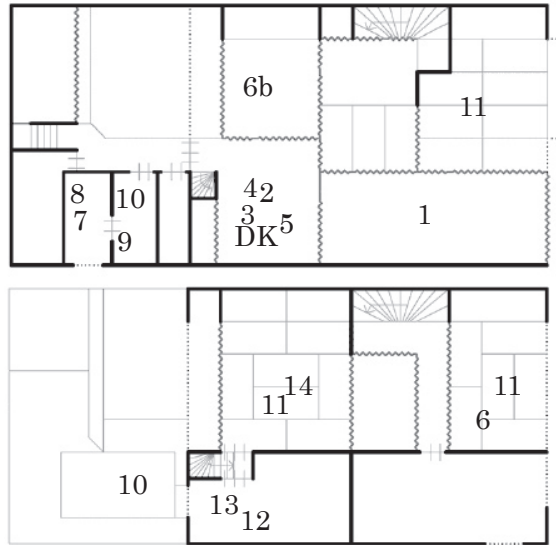

First Floor

Fig. 18 Case 2: 1 Entering; 2 Breakfast; 3 Lunch; 4 Dinner; 5 Cooking; 6 Sleeping; 6b Sleeping 2; 7 washing (shower); 8 bathing; 9 clothes washing; 10 clothes drying; 11 Leisure; 12 Study/reading; 13 Work; 14 Tea ceremony; DK dinning kitchen.

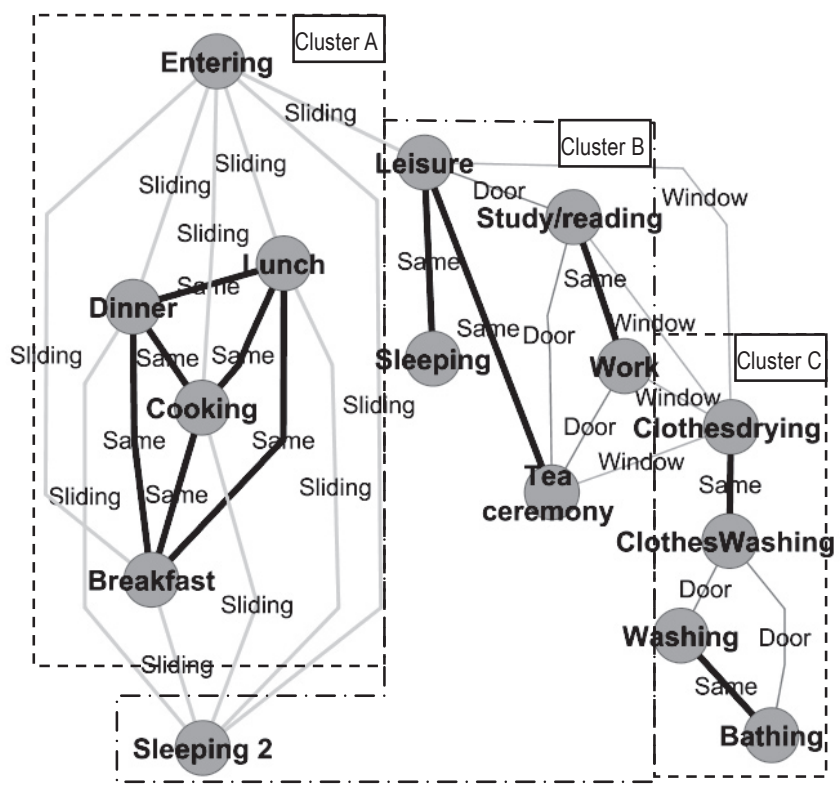

Fig. 19 Syntactic activity graph (drawn using Cytoscape) corresponding to Case 1. Dotted lines indicate clusters as in Fig. 20.

The first particularity we can observe is that cooking is connected to the eating activities with a "Same" type of connector shown in the syntactic activity graph (Fig. 19), because of the dining kitchen interrupting the tooriniwa.

A second particularity is that doors appear in an area corresponding to tea ceremony and a space for study/reading and work (Fig. 19); this odd configuration corresponds to a room in 


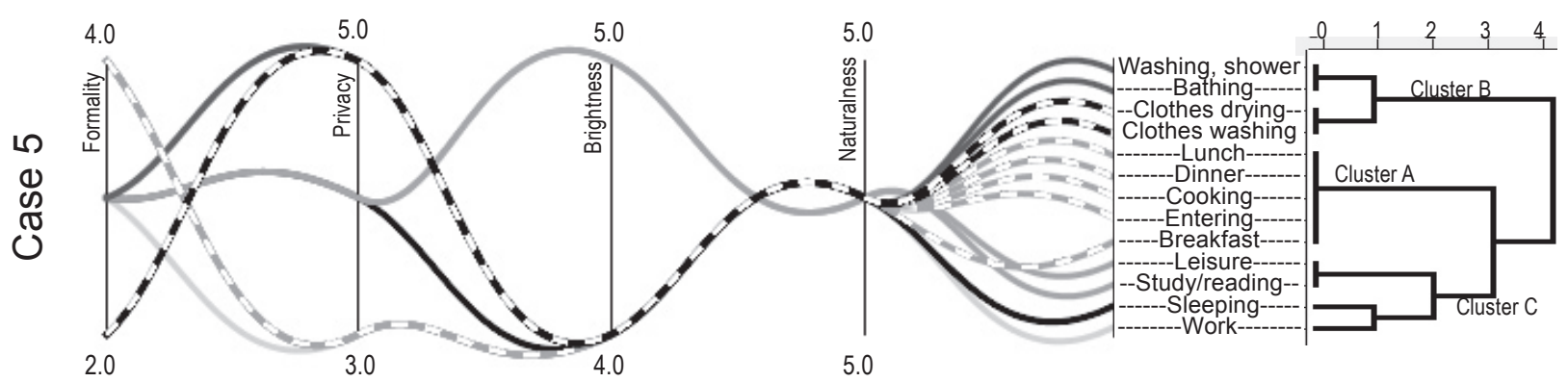

Fig. 20 Parallel coordinates representing the semantic data provided by inhabitant of case 5and Dendrogram of cluster analysis of such data.

the second floor arranged to be used for tea ceremony and a new added studio located over the new dining kitchen (Fig. 18) (a tea house at the back of the house is now used as storage).

The third particularity would be that a second sleeping activity appears in the former zashiki (Fig. 18).

Finally in the rear part of the tooriniwa space for washing, bathing and clothes washing remains in a similar disposition as in Machiya.

In order to put the case with its particularities in context, we can see the particular semantic information of this case in Fig. 20. Firstly we can notice a main formal cluster composed of cook/eating functions and "entering" (Cluster A in Fig. 20). A functional core located connected to the entrance; a dinning kitchen directly accessible from the doma.

As for the second particularity, we can recognize that study/reading appear with high brightness together with Leisure (Fig. 20).

While as for the third particularity sleeping appears more private and formal than in Machiya.

Semantically only 5 activities remain with a similar formality and privacy as Machiya: In Fig 20 we see the entering remains formal-public; clothes washing and clothes washing remain informal-private; while washing (shower) and bathing are not formal nor informal (middle formality in Fig. 20), but still private, and as in Machiya (Fig. 2) such activities are among the most formal of the informal private activities, we still consider them similar.

The semantic clustering (Fig. 20) tends to match Fig. 19 except for Sleeping 2, which is in Cluster B, but more connected to A.

\section{Conclusions}

We were able to assess the inhabitants' perception of a vernacular dwelling typology in a wide scope context collecting data from 223 inhabitants, and applied such perception as the context for analyzing specific cases. Making it possible to define the dwelling typology in part $1^{4)}$ (in this case Machiya), using the inhabitants interpretation. And then, in this part, we use the same framework of semantic data to analyze specific cases and complement such analysis with additional syntactic analysis.

As result we could understand in which aspect each case is related or not to Machiya typology identified with the semantic analysis of Machiya (compared with other typologies in part 14)).

We could establish in each case the relation of the spatial connections of activities (syntactic analysis) with the actual perception of the inhabitant (semantic analysis), which corresponds to the pragmatic level of the analyzed typology.

We can classify the cases as follows:

If the syntactic analysis and semantic clustering matches, we consider the case as semantically and syntactically coherent (SSC); if the semantic description of the majority of activities has formality and privacy similar to Machiya we consider the case as semantically Machiya (SeM), and syntactically Machiya (SyM) if we can recognize syntactic structures of Machiya such as tooriniwa and formal rooms.

-In case 1 we found an example of coherence in inhabitation and space, SSC, SeM and SyM.

-In case 2 we could find an example of Machiya where despite of physical damage is still SSC and SyM, but not SeM.

-In case 3 we can see an example of how a severely modified Machiya is not only syntactically but semantically converted in a shared house. SSC as share house, but not SeM nor SyM.

-In case 4 we can see an example of Machiya not SyM, but SSC and SeM, showing that it is possible to make new types of Machiya even with many changes (Machiya with new forms).

-In case 5 we can see an example of impact caused in a partially reformed Machiya, only SSC despite the external appearance.

From the case studies we can conclude that in all cases there are mainly two types of factors creating the architecture of each case. One factor is the physical changes in the building itself, and another is the interpretation of each inhabitant. For this reason we consider that each work of architecture is result of collaboration between architect and inhabitant. Especially in the cases of modified houses, corresponding to great part of the remaining Machiya in Kyoto, each inhabitant is an active part of the design process, and not only those who actually physically modify a house, but also the architecture making process is actively made by the inhabitant who do not physically modify buildings, but gives them a meaning by interpreting them as he inhabit in them. In other words, inhabitation is a creative form of interpretation, as in the case of C.S. Peircian concept of semiosis, 
an interpretant is created from the interpreted sign (CP 2.228)28).

Therefore, if the inhabitant is involved in part of the design process, we can consider the architect as collaborator in the design process rather than author of design.

Also we were able to notice when small changes have big semantic impact or when changes can be semantically coherent with certain typology.

Finally as we can see certain activities more frequently modified than others, future research might aim on activities instead as buildings, and still we could use a similar method.

\section{Acknowledgements}

We would to thank to all who answered the questionnaire. Also we would like to thank to those who helped voluntarily to distribute the questionnaire and help for case studies: Ms. A. Nishii, Ms. F. Kojima, Ms. M. Kimura, Mr. K. Arakawa, Mr. K. Matsui, Mr. T. Takahashi, Mr. R. Kinoshita, Mr. D. Ialnazov, Mr. G Moussas, Mr. A. Nahmias and Mr. M. Mora.

This research is supported by Grant-in-Aid for scientific research (B): "Semiotic Study on Townscape Design based on Community Governance" (Leader: Teruyuki Monnai), by Japan Society for the Promotion of Science (JSPS).

\section{Notes}

*1) "Museumization" in this case we refer to it as explained by McDonough $^{1)}$ referring to the lack of meaning in the cities, citing as well Debord ${ }^{2)}$, who points out the rather utilitarian urban design signifying nothing.

*2) The terms "hypersignificant and Hyposignificant, are based on the theory of Francoise Choay ${ }^{3)}$ concerning the loss of meaning of public space in modern context.

*3) In part $1^{4)}$ we collected data from Machiya and other dwelling types in order to compare and establish the contemporary context of Machiya, in this paper we focus on selected cases.

*4) Previously we investigated external contest of Machiya ${ }^{5)}$.

*5) In part $1^{4)}$ we found that the inhabitants are able to differentiate dwelling typologies including Machiya in a way which is coherent with traditional Machiya, but showing it in nowadays context.

*6) The list of activities is based on 図説 日本人生活時間 $1990^{23)}$, with some changes, focusing more on spaces within a dwelling.

*7) See 京町家まちづくり調查 ${ }^{25)}$ answers to question 8 .

*8) In part $1^{4}$, we made the same type of graph for different dwelling typologies and compared the graphs; thus we know that the Machiya graph resembles more to the Machiya layout than the others.

*9) The updated data distribution is as follows: 45 people living in Machiya, 68 living in other type of houses, and 108 people living in apartment buildings or others and 2 who did not specify; 116 male, 112 female, 2 did not specify. According to age the distribution is the following: from 0-29: 72; from 30 to 39: 49; from 40 to 49: 16; from 50 to 59: 16 ; from 60 to 69 : 37; 70 and over: 26 ; and 3 did not specify age. According to nationality 176 are Japanese, 40 non Japanese and 3 did not specify. For more detail refer to part $1^{4}$. The new data was received in the same method (same questionnaire) as the 215 answers of part $1^{4)}$. Part 1 included data collected from February to April 2012, and part 2 includes data received up to June 2012 (by post or online).

*10) In this paper we will not refer in detail to the other dwelling types as they where explained in part $1^{4)}$, but focus on case studies.

*11)KNIME is an open-source platform for data mining, initially developed at the University of Konstanz, Germany.
*12) To better illustrate the process a floor plan is added in analysis. For example of multiple linkages, in Fig. 4 in the first floor we can see twice Guests' Sleeping activity (6G) in contiguous rooms, but one room also hosts activities $2 \mathrm{G}, 3 \mathrm{G}, 4 \mathrm{G}, 11$ and 13 , additionally activity $6 \mathrm{G}$ is also present in the second floor, hence in Fig. 6 the activity Guests' Sleeping has multiple connectors including a connector to itself.

\section{References}

1) McDonough, Thomas F., Situationist Space Vol. 67 pp. 58-77, the MIT press, 1994

2) Debord, Guy-Ernest, Introduction to a Critique of Urban Geography,

3) Choay, Francoise, Semiologie et urbanisme, L'Architecture d'Aujourd'hui 132, 1967.

4) Jander, Fabian and Monnai, Teruyuki: Semantic Analysis of Machiya Inhabitation Context -Culturally Friendly Design Method based on Machiya System of Kyoto (Part 1), J. Archit. Plann., AIJ, Vol. 78, No. 685, pp. 573-583, 2013.3

5) Jander, Fabian and Monnai, Teruyuki: Parametric Analysis of Machiya Context using Semiotic Indicators, J. Archit. Plann., AIJ, Vol. 77, No. 676, pp. 1343-1353, 2012.6

6）丸山俊明：京都の町家と梁間規制に関する論文, J. Archit. Plann., AIJ, No. 606 , pp. 169-174, 2006.8

7）大場修：奈良盆地における町家の発展過程，日本建築学会計画系論文報 告集，第 403 号, pp. 133-147, 1989.9

8）石田秀樹，荒谷登，佐々木隆，絵内正道：開放系住居の夏の環境特性，日 本建築学会計画系論文報告集，第408 号, pp. 23-32, 1990.2

9）丸山俊明：京都の町家と町なみ一何方を見申様に作る事，堅仕間敷事，昭 和堂, 2007

10）丸山俊明: 町家の真壁と京町家奉行所の建築行政, J. Archit. Plann., AIJ, No. 596, pp. 163-168, 2005.10

11）高橋康夫：京・まちづくり史，昭和堂, 2003

12）高橋康夫，宮本雅明，吉田伸之，伊藤毅：図集 日本都市史，東京大学出版 会, 1993

13）今和次郎：日本の民家，岩波書店, 1989

14) Löfgren, Karin: Machiya, architecture and history of the Kyoto town house, doctor dissertation of KTH Royal Institute of Technology, 2003

15）松井薰: “京町家塾 町家って何?”(京町家再生 vol.2), 京町家再生研 究会助成プログラムの活動より, 2001

16）尹孝鎮，三村浩史，リムボン：京都の歴史的都心地区における町家居住 者・営業者の町家維持と継承意向に関する研究，J. Archit. Plann., Environ. Engng. AIJ, No. 453, pp. 105-111, 1993.11

17) Salastie, Riita: Living Tradition or Panda `s Cage, Helsinki University of Technology, 2001

18）巽和夫：町家型集合住宅一成熟社会の都心居住へ, 学芸出版社, 1999

19）宗田好史：町家再生の論理一創造的まちづくりへの方途，学芸出版社, 2009

20) 河本光正, 藤木隆男: 京都市中心部における町家分割利用の空間的特徵に 関する研究, J. Archit. Plann., Environ. Engng. AIJ, No. 549, pp. 307-314, 2001.11

21）木川剛志，古山正雄 : スペース・シンタックス理論による空間位相構成の 抽出とその比較に関する研究, J. Archit. Plann., Environ. Engng. AIJ, No. 597, pp. 9-14, 2005.11

22）青木芳次, 藤原 学：町家平面のスキームグラマー, J. Archit. Plann. Environ. Engng. AIJ, No. 455, pp. 119-127, 1994.1

23） NHK 世論調查部：図説日本人生活時間 1990, 日本放送出版協会, 1992

24) Tanizaki, Jun'ichiro: In Praise of Shadows, Leete's Island Books, 1977

25）京都市：京町家まちづくり調査（平成 20-21 年度），2011

26) Daniels, Inge: The Japanese House: Material Culture in the Modern Home, Berg, 2010

27) Nyunt, Koung: Study on Japanese Traditional Living Space and Landscaping, doctor dissertation, 1978

28) Hartshorne, Charles and Weiss, Paul (eds.): Collected Papers of Charles Sanders Peirce Vol.1 and Vol.2, The Belknap Press of Harvard Univ. Press, 1978 


\section{和文要約}

本論文では、町家と改変された町家の事例分析を行っている。前 論文（その 1 ）では、町家の居住タイプを理解するために意味論的 指標が使用したが、本論文では同じ方法を用いて個別事例を分析し、 町家と比較するとともに、それらが町家とどのように関連している かを調べるために、補完的に構文論的分析も行っている。

\section{1. 町家の概念}

本研究では、居住者の解釈（意味論）に基づいて、町家の定義と して、構文論的定義よりも意味論的定義を採用する。

\section{2. 意味論的分析}

意味論的分析のために、我々はまず表一裏、ハレーケ、内一外と いった伝統的概念から導き出された意味論的指標を用いて町家を記 述する。そこでは「形式性」(formality) と「プライバシー」(privacy) という 2 つの主要な意味論的次元が導き出される。次いで、「明る さ」(brightness) と「自然性」(naturalness) という2つの意味論 的次元が導入される。これらの次元は、町家における奥庭や坪庭、 及び光と影という美学的な含意に対応する。

そこで我々は、これらの 4 つの意味論的次元を踏まえて、13の生 活行動 (1-玄関から入る, 2 -朝食をとる, 3-昼食をとる, 4-夕食をとる, 5-調理をする，6-睡眠をとる，7-身体を洗う（シャワーをする），8-入 浴する，9-衣服を洗濯する，10-衣服を乾かす，11-レジャーを楽しむ， 12-勉強する／読書する，13-仕事をする）について居住者に質問し、 回答を得た。このとき、意味論的次元に関する現状だけでなく、好 みとともに、望ましい居住類型についても尋ねた。

データの集計に当たっては、町家、町家以外の戸建て低層住宅、 高層集合住宅といった居住類型別に集計し、居住類型にしたがって、 各生活行動について意味論的次元の平均值を算出した。こうしたプ ロセスの結果として、各居住類型に対して、13の生活行動をプロッ トした 4 次元のグラフを得た。これらのグラフを比較することによ って、それぞれの居住類型を意味論的に比較することができる。

\section{3. 構文論的分析}

我々は、意味論的分析とともに、それぞれの事例に構文論的分析 を適用する。構文論的分析に用いたデータは、ケーススタディとし て取り上げた住宅を訪衩て収集した。各事例は、改変された町家が いかにして町家であり続けるかを理解するために選択されたもので ある。ケーススタディの調査対象者には、（その 1 ）で用いた質問紙 に回答するとともに、質問紙に掲げられた生活行動が住宅内のどの 空間で生じているかを説明することを求めた。

構文論的分析のための手法としてはグラフ理論を用いている。 我々は質問紙に提示されている 13 の生活行動をグラフの頂点とし て位置づけ、グラフの各辺には生活行動を相互に関連づける建築的 要素を示すラベルが付与されている。同じ空間で行われる生活行動

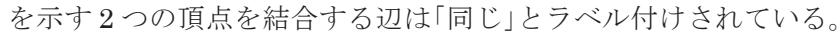

\section{4. 実用論的分析：意味論的分析と構文論的分析の関係}

ケーススタディから得られたデータは、意味論的次元を通して(そ
の 1 ）で分析された意味論的コンテクストと結びつけられている。 それゆえ、個々の事例は、たとえ単一の事例であってもそれぞれの 意味を理解することができるように選択されている。

意味論的データに用いることよって、どのような生活行動が意味 論的に相互に関連し合っているかを発見することができる。構文論 的分析によって、我々は、意味論的に関連づけられた生活行動が空 間的に結びつけられているか、あるいは住居の空間構造と対応づけ られているかを明らかにすることができる。居住者の解釈とコンテ クストとの関係は、実用論的次元に対応しているのである。

\section{5. 改変された町家に適用された分析}

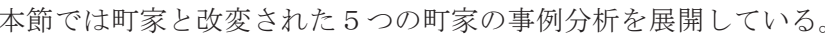
(1)町家空間を知覚する伝統的方式を示してくれる代表的な町家。 (2)外国人建築家が住んでいる非常に伝統的方式で修理された町家。 町家の構文論的秩序はよく保存されている。意味論的クラスターも 町家と合致しているが、新たな意味論的秩序も知覚されている。 (3)シェアハウスとしてリフォームされた大きく改変された町家。 この事例では、町家の意味論的秩序も構文論的秩序も保存されてい るが、意味味論的クラスターは、共有された行動とプライベートな 行動の組合せによって定義されることを発見した。

(4)1 階にオフィス空間、2 階に住居を置いた新しい配置を持つ町家。 この事例から、異なる構文論的秩序をもつ場合でも、ほとんどの生 活行動に対して町家の意味論的秩序を維持できることを発見した。 (5)意味論的秩序を変える新しいダイニング・キッチンを設けた町家。

\section{6. 結論}

223 人の居住者から収集したデータを用いて、我々は、居住者が 伝統的住居のタイポロジーをどのように知覚しているかを評価する ことができる。そして、一般的な意味論的データを特定の事例分析 のための枠組みとして使用するとともに、付加的に構文論的分析を 導入して意味論分析を補完する試みを展開した。

その結果、各事例が町家の意味論的分析によって導き出された町 家のタイポロジーとの関連を理解することができる。実際、5つの 事例において、生活行動の空間的な結合（構文論的分析）と居住者 による空間の解釈（意味論的分析）との関係、すなわち実用論的レ ベルに対応する関係を確立することができた。

これらのケーススタディから、建築を創造する 2 つ主要な要因 が存在すると結論づけることができる。一つの要因は、建物それ自 体における物理的な変化であり、もう一つの要因は、居住者の解釈 である。それゆえ我々は、建築作品は建築家と居住者のコラボレー ションの結果であると考えている；居住者、すなわち、住みながら 建物を解釈することによって、建物に意味を付与する人々は、実は デザインプロセスでアクティブな役割を果たしていると言える。

さらに我々は、小さな変化が意味論的に大きな影響を持つ場合、 あるいはそのような変化が特定の意味論的タイポロジーとして現れ る場合を発見することができる。

以上のように、人間行動は建築空間に大きな影響を及ぼすもので あり、将来の研究は人間行動を目指して行われることになるだろう。

（2012年12月10日原稿受理，2013年 5 月17日採用決定） 